\title{
Pembuatan Alur Pelayaran dalam Rencana Pelabuhan Marina Pantai Boom, Banyuwangi
}

\author{
Muhammad Didi Darmawan, Khomsin \\ Jurusan Teknik Geomatika, Fakultas Teknik Sipil dan Perencanaan, Institut Teknologi Sepuluh Nopember (ITS) \\ Jl. Arief Rahman Hakim, Surabaya 60111 Indonesia \\ e-mail: Khomsin@geodesy.its.ac.id
}

\begin{abstract}
Abstrak-Pantai Boom merupakan pantai yang ada di Kabupaten Banyuwangi. Pantai ini terletak di Kelurahan Kampung Mandar, Kecamatan Banyuwangi, Banyuwangi, Jawa Timur. Pantai tersebut rencananya akan dibangun pelabuhan marina. Pelabuhan harus dilengkapi dengan beberapa fasilitas untuk mendukung rencana tersebut seperti salah satunya adalah alur pelayaran. Untuk membuat alur pelayaran diperlukan penelitian mengenai pasang surut, topografi dasar laut, serta jenis kapal yang melintas untuk memastikan kapal yang berlayar aman dari kemungkinan kecelakaan. Penelitian ini menggunakan data hasil pemeruman, data pasang surut yang diperoleh dari pengamatan langsung, serta berbagai jenis kapal yacht. Hasil dari penelitian ini didapatkan bahwa rencana dermaga sebaiknya dibangun 60 meter menjorok ke arah laut dengan panjang dermaga 25 meter. Dalam keadaan air rendah terendah (LLWL), ketiga jenis kapal yang ditentukan dapat merapat ke rencana Dermaga Pelabuhan Marina Pantai Boom, Banyuwangi. Daerah yang tidak bisa dilewati pada saat LLWL, pada saat MSL daerah tersebut sudah dapat dilewati oleh ketiga jenis kapal tersebut. Pada keadaan muka air tinggi tertinggi (HHWL), Kapal Yacht Class 8 dan 6 dapat melewati sebagian perairan sungai Pantai Boom. Waktu yang tidak tepat untuk melakukan pelayaran pada saat LLWL dari alur pelayaran yang telah dibuat yaitu antara pukul 04:00 - 06:00 WIB pada saat bulan November 2015Februari 2016 dan pukul 16:00-18:00 pada saat bulan JuniAgustus 2016. Sedangkan Waktu yang tepat untuk melakukan pelayaran pada saat HHWL yaitu antara pukul 20:00-23:00 WIB pada saat bulan Desember 2015- Maret 2016 dan pukul 8:00-11:00 pada saat bulan Juni-September 2016.
\end{abstract}

Kata Kunci_alur, kapal, Pantai Boom, Pelabuhan Marina

\section{PENDAHULUAN}

$\mathrm{P}$ ANTAI Boom adalah salah satu pantai yang ada di Kabupaten Banyuwangi. Pantai ini terletak di Kelurahan Kampung Mandar, Kecamatan Banyuwangi, Banyuwangi, Jawa Timur. Pantai ini rencananya akan dibangun pelabuhan marina dimana peluncuran pembangunannya digelar di Pantai Boom, 12 September 2015.

Untuk mendukung rencana tersebut, pelabuhan harus dilengkapi dengan fasilitas seperti pemecah gelombang, dermaga, peralatan tambatan, peralatan bongkar muat barang, gudang-gudang, perkantoran baik untuk maskapai pelayaran dan pengelola pelabuhan, dan khususnya adalah alur pelayaran [1]. Salah satu hal yang tidak boleh ditinggalkan dalam proses pembangunan pelabuhan adalah ketersediaan alur pelayaran. Alur pelayaran digunakan untuk mengarahkan kapal yang akan keluar/masuk ke kolam pelabuhan. Alur pelayaran harus mempunyai kedalaman dan lebar yang cukup atau sesuai dengan draft kapal sehingga dapat dilalui kapal-kapal yang akan menggunakan pelabuhan.

Dengan mengetahui secara pasti data pasang surut, jenis kapal yang akan berlabuh, serta peta batimetri yang memuat data kedalaman dasar perairan, maka akan didapat analisis daerah yang bisa dilewati pada saat muka air rendah terendah, muka air rerata, dan muka air tinggi tertinggi sesuai jenis kapal yang ditentukan untuk merapat ke rencana Dermaga Pelabuhan Marina Pantai Boom, Banyuwangi. Analisis selanjutnya yaitu tipe dermaga yang akan dibangun, serta waktu yang tidak tepat untuk melakukan pelayaran saat keadaan alur pelayaran muka air rendah terendah dari alur pelayaran yang telah dibuat dan waktu yang tepat untuk melakukan pelayaran saat keadaan alur pelayaran muka air tinggi tertinggi dari alur pelayaran yang telah dibuat.

Diharapkan penelitian ini dapat memberikan manfaat berupa rekomendasi tentang pembuatan alur pelayaran kepada pihak terkait dalam perencanaan Pelabuhan Marina Pantai Boom, Banyuwangi.

\section{METODOLOGI PENELITIAN}

\section{A. Lokasi Penelitian}

Lokasi penelitian tugas akhir ini mengambil daerah studi Pantai Boom yang terletak di Kelurahan Kampung Mandar, Kecamatan Banyuwangi, Banyuwangi, Jawa Timur. Secara geografis terletak antara $08^{\circ} 10^{\prime} 45^{\prime \prime}$ LS - 08 13 '40" LS dan $114^{\circ} 22^{\prime} 50^{\prime \prime}$ BT - $114^{\circ} 24^{\prime} 10^{\prime \prime}$ BT

\section{B. Data dan Peralatan}

1) Data

Data yang digunakan dalam penelitian ini adalah:

a. Data pasang surut di daerah pantai boom selama 15 hari yang didapat dari pengamatan langsung pada rentang tanggal 5-19 Nopember 2015.

b. Data batimetri yang diambil secara langsung di daerah tersebut pada rentang tanggal 07-15 Nopember 2015.

c. Data topografi dari pengukuran langsung pada rentang tanggal 1-10 Nopember 2015 di daerah Pantai Boom, Banyuwangi. 


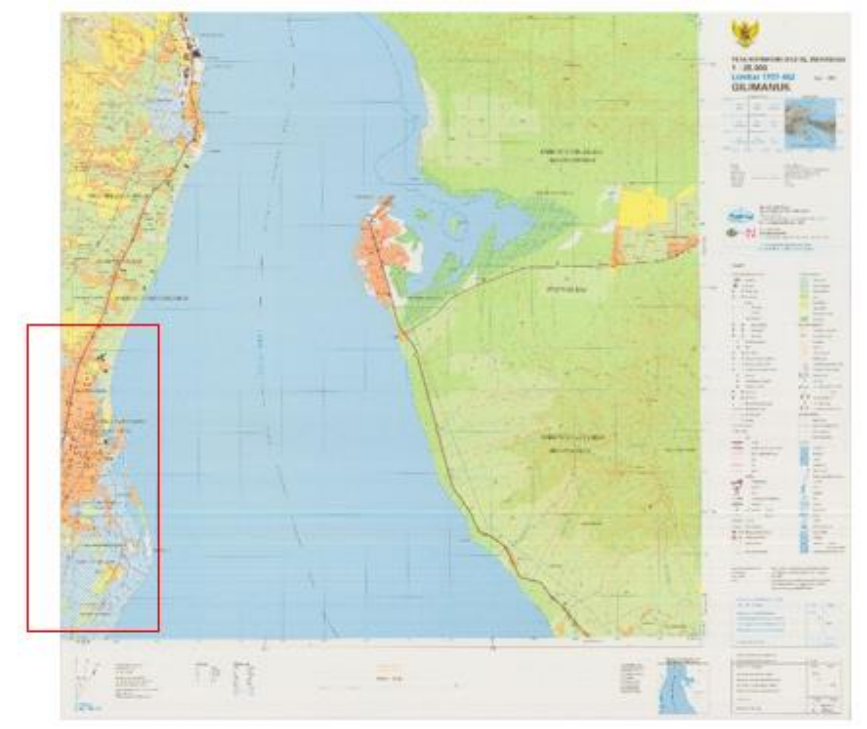

Gambar. 1. Lokasi Penelitian

2) Peralatan

Peralatan yang digunakan dalam penelitian ini berupa perangkat keras 1 unit PC computer dan perangkat lunak pengolahan data spasial.

\section{Metodologi Pekerjaan}

Penjelasan diagram alir metodologi pekerjaan pada Gambar 2. adalah:

1) Tahap Persiapan

Pada tahap ini, kegiatan-kegiatan yang dilakukan adalah:

a. Identifikasi Awal

Kegiatan ini bertujuan untuk mengidentifikasi penelitian yang akan dilakukan. Identifikasi tersebut berupa latar belakang, perumusan masalah, batasan masalah, tujuan dan manfaat.

b. Studi Literatur

Kegiatan ini bertujuan untuk memperoleh referensi yang berhubungan dengan survei hidrografi, kapal, spesifikasi alur pelayaran, dan penelitian sebelumnya.

\section{c. Pengumpulan Data}

Kegiatan ini bertujuan untuk mengumpulkan data dan peralatan yang digunakan.

2) Tahap Pengolahan dan Analisis

Pada tahapan ini dilakukan pengolahan data yang telah didapat dan data penunjang lainnya, kemudian dilakukan Analisis pada keseluruhan perolehan data. Kegiatan ini meliputi:

\section{a. Pengolahan Data}

Pengolahan data yang dilakukan dalam penelitian ini adalah pengolahan dari data-data survey hidrografi dan data topografi yang telah diambil dari lapangan. Selanjutnya dari pengolahan tersebut dilakukan perencanaan alur pelayaran yang disesuaikan dengan draft dan lebar kapal maksimum.

b. Analisis Data

Data yang telah diolah kemudian dianalisis sedemikian rupa sehingga diperoleh suatu hasil berupa analisis daerah yang bisa dilewati pada saat muka air rendah terendah, muka air rerata, dan muka air tinggi tertinggi sesuai jenis kapal yang ditentukan untuk merapat ke rencana Dermaga Pelabuhan Marina Pantai Boom, Banyuwangi. Analisis selanjutnya yaitu tipe dermaga yang akan dibangun, serta waktu yang tidak tepat untuk melakukan pelayaran dari alur pelayaran yang telah dibuat.

3) Tahap Akhir (Penyusunan Laporan)

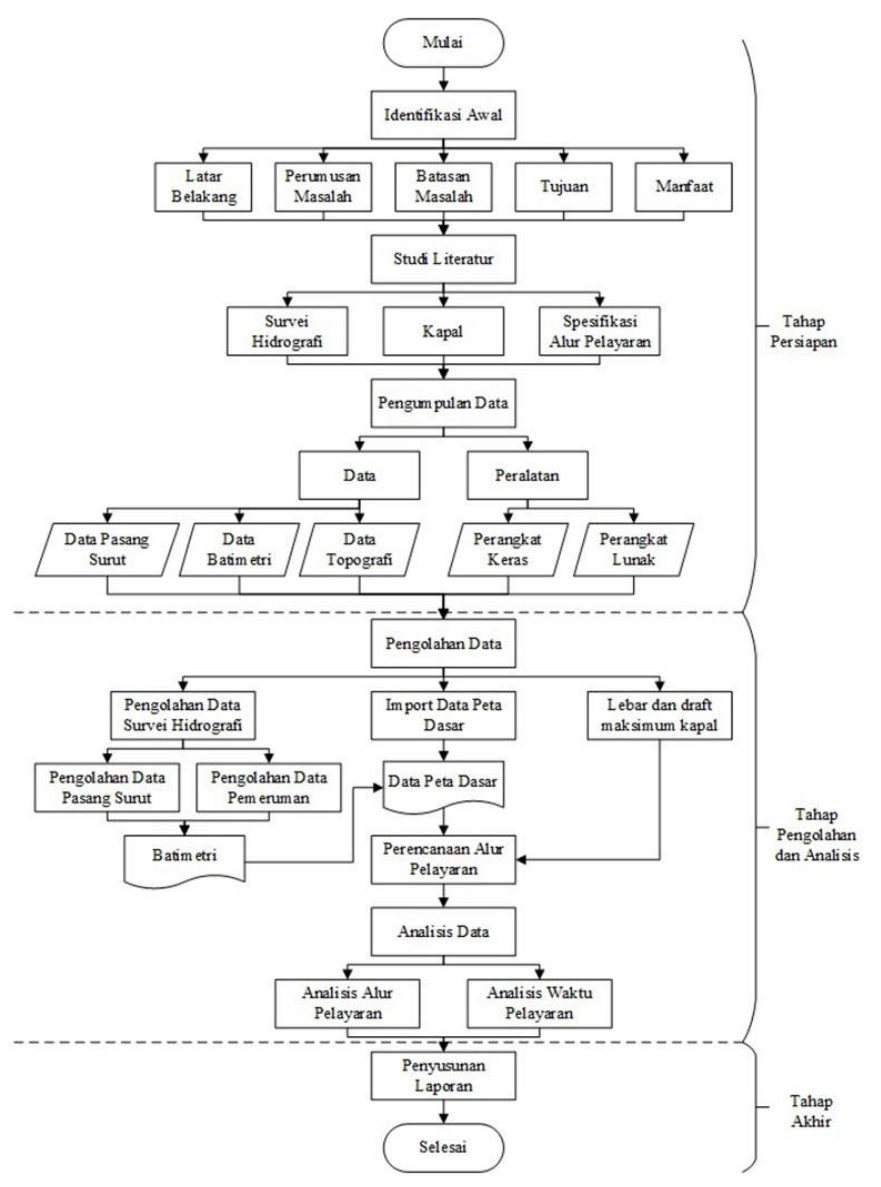

Gambar. 2. Diagram Alir Metodologi Pekerjaan

\section{HASIL DAN PEMBAHASAN}

\section{A. Hasil dan Analisis Pengolahan Pasang Surut}

Pasang surut dalam penelitian ini yaitu berada pada Stasiun Pantai Boom. Pasut Stasiun Pantai Boom diperoleh dengan pengamatan langsung selama 15 hari. Data pengamatan pasut tersebut kemudian diolah dengan menggunakan metode Least Square untuk memperoleh konstanta harmonik pasang surut.

Tabel 1.

Hasil Perhitungan Komponen Pasang Surut Pantai Boom, Banyuwangi

\begin{tabular}{cccccc}
\hline \hline Symbol & $\begin{array}{c}\omega \\
(\mathrm{rad} / \text { hour })\end{array}$ & $\mathrm{A}$ & $\mathrm{B}$ & $\begin{array}{c}\mathrm{g}^{\mathrm{o}} \\
\text { phase }\end{array}$ & $\begin{array}{c}\text { Amplitude } \\
(\mathrm{m})\end{array}$ \\
\hline $\mathrm{Z}_{0}$ & - & & & & 1,341 \\
$\mathrm{M}_{2}$ & 0,505 & $-0,452$ & $-0,410$ & $222,217^{\circ}$ & 0,610 \\
$\mathrm{~S}_{2}$ & 0,523 & 0,351 & 0,226 & $32,831^{\circ}$ & 0,418 \\
$\mathrm{~N}_{2}$ & 0,496 & $-0,070$ & 0,091 & $127,486^{\circ}$ & 0,115 \\
$\mathrm{~K}_{2}$ & 0,525 & $-0,072$ & $-0,080$ & $228,024^{\circ}$ & 0,107 \\
$\mathrm{~K}_{1}$ & 0,262 & 0,268 & $-0,152$ & $330,445^{\circ}$ & 0,309 \\
$\mathrm{O}_{1}$ & 0,243 & 0,070 & $-0,074$ & $313,335^{\circ}$ & 0,102 \\
$\mathrm{P}_{1}$ & 0,261 & $-0,160$ & 0,339 & $115,255^{\circ}$ & 0,375 \\
$\mathrm{M}_{4}$ & 1,011 & $-0,015$ & $-0,008$ & $209,950^{\circ}$ & 0,017 \\
$\mathrm{MS}_{4}$ & 1,029 & 0,024 & 0,000 & $0,299^{\circ}$ & 0,024 \\
\hline \hline
\end{tabular}


Dari hasil pengolahan menggunakan metode Least Square terhadap data Pasang Surut pengukuran langsung 15 hari, didapat konstanta harmonik pasang surut Stasiun Pantai Boom pada 5-19 Nopember 2015 seperti pada Tabel 1.

Dari hasil perhitungan komponen pasut, selanjutnya adalah mencari bilangan Formahzl menggunakan rumus [2]:

$$
F=\frac{K 1+O 1}{M 2+S 2}
$$

$$
\begin{aligned}
& \mathrm{F}=\text { bilangan Formahzl } \\
& \mathrm{O} 1=\text { amplitudo komponen pasang surut tunggal utama } \\
& \text { yang disebabkan oleh gaya tarik bulan. }(\mathrm{cm}) \\
& \mathrm{K} 1=\text { amplitudo komponen pasang surut tunggal utama } \\
& \text { yang disebabkan oleh gaya tarik matahari. }(\mathrm{cm}) \\
& \mathrm{M} 2 \text { = amplitudo komponen pasang surut ganda utama } \\
& \text { yang disebabkan oleh gaya tarik bulan. }(\mathrm{cm}) \\
& \text { S2 = amplitudo komponen pasang surut ganda utama }
\end{aligned}
$$

Hasil perhitungan bilangan Formahzl pasut Pantai Boom adalah sebesar 0,40. Karena hasil bilangan Formahzl Pantai Boom antara 0,25-1,5, maka pasut Pantai Boom bertipe campuran condong ke harian ganda [3]. Penentuan referensi tinggi dari data pasang surut dengan referensi LLWL, MSL, dan HHWL ditentukan dengan rumus sebagai berikut [4]:

$$
\begin{aligned}
& L L W L=\mathrm{Z}_{0}-\left(\mathrm{M}_{2}+\mathrm{S}_{2}\right)-\left(\mathrm{O}_{1}+\mathrm{K}_{1}\right) \\
& M S L=\mathrm{Z}_{0} \\
& H H W L=\mathrm{Z}_{0}+\left(\mathrm{M}_{2}+\mathrm{S}_{2}\right)+\left(\mathrm{O}_{1}+\mathrm{K}_{1}\right)
\end{aligned}
$$

Dengan rumus tersebut, didapat hasil $\mathrm{LLWL}=-0,099$ meter, MSL $=1,341, \mathrm{HHWL}=2,782$ meter. Dari hasil komponen pasang surut yang telah diperoleh pada tabel 1, selanjutnya adalah melakukan prediksi pasang surut untuk mengetahui perbedaan tinggi dan waktu pasang surut setiap jam selama satu tahun. Dari prediksi pasang surut yang telah dibuat, maka dapat ditentukan waktu yang tepat untuk digunakan dalam melakukan pelayaran di daerah Pantai Boom.

\section{B. Hasil dan Analisis Kedalaman Perairan}

Untuk memudahkan analisis kedalaman perairan di area Pantai Boom, maka area perairan perlu diklasifikasi menjadi 4 bagian.

Tabel 2.

International Rule Yacht

\begin{tabular}{cccccc}
\hline \hline Class & $\begin{array}{c}\text { Rated } \\
\text { length, } \mathrm{m}\end{array}$ & LOA, m & Beam, m & $\begin{array}{c}\text { Draft, } \\
\mathrm{m}\end{array}$ & $\begin{array}{c}\text { Displ, } \\
\text { tons }\end{array}$ \\
\hline $12(1)$ & 12,00 & 21,40 & 3,60 & 2,70 & 25,3 \\
$12(2)$ & 12,00 & 20,27 & 3,60 & 2,80 & 28,6 \\
$8(1)$ & 6,78 & 14,02 & 2,21 & 1,98 & 8 \\
$8(2)$ & 6,78 & 15,03 & 2,51 & 1,98 & 9 \\
$6(1)$ & 6,00 & 10,67 & 1,91 & 1,52 & 3,15 \\
$6(2)$ & 6,00 & 11,73 & 1,83 & 1,68 & 4,02 \\
\hline \hline
\end{tabular}

Pembagian kedalaman tersebut yaitu batas kedalaman Kapal Yacht 12, Yacht 8, Yacht 6 dan batas kedalaman yang tidak bisa dilewati ketiga jenis kapal tersebut. Spesifikasi dari Kapal Yacht dapat dilihat pada Tabel 2 [5].

Tabel 3.

Pembagian Kedalaman

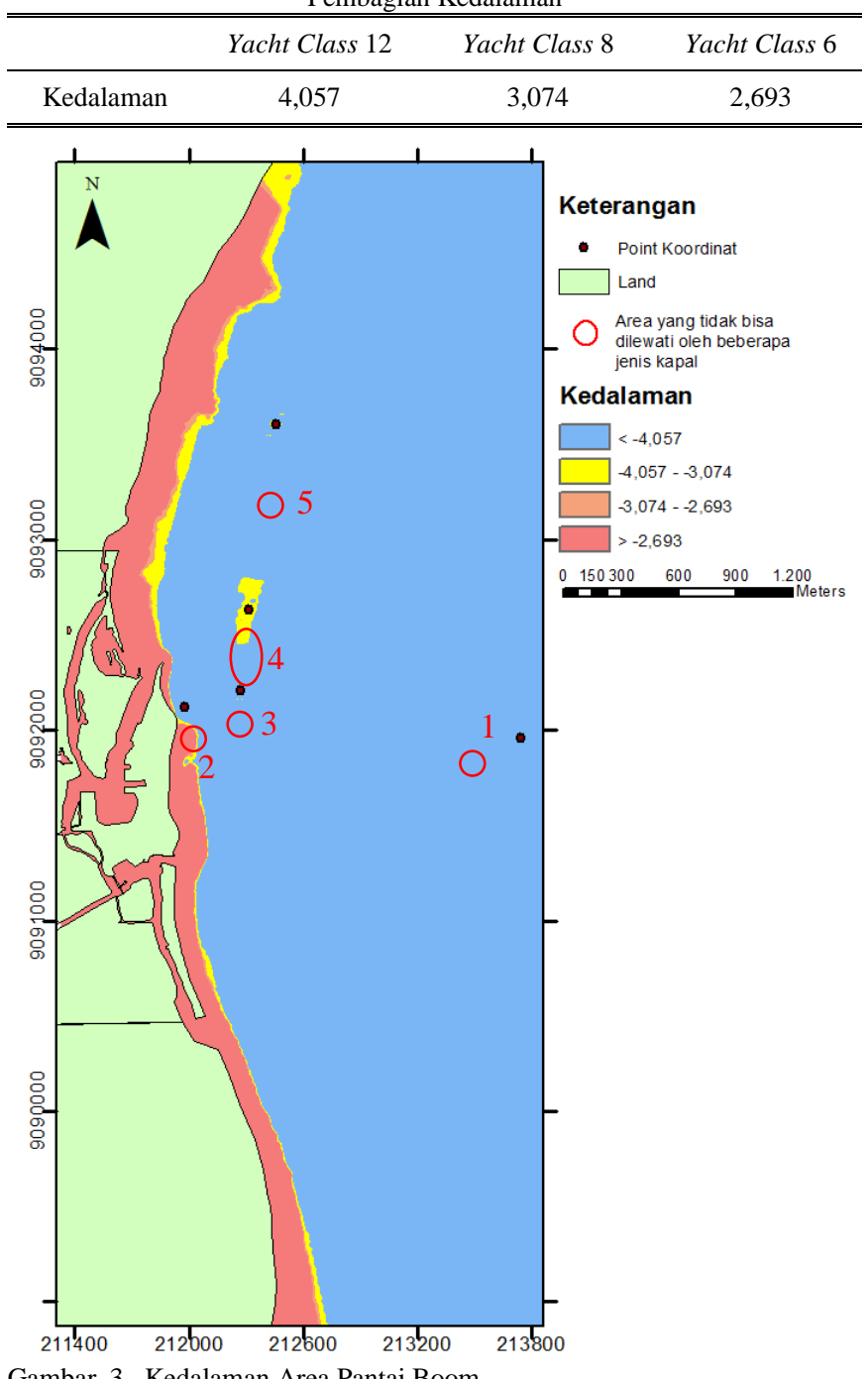

Gambar. 3. Kedalaman Area Pantai Boom

Penentuan batas kedalaman diperoleh dengan menggunakan rumus 5 [4] yaitu:

$$
H=d+G+R+P
$$

Dengan kedalaman alur $(\mathrm{H})$, draft kapal (d), gerak vertikal kapal karena gelombang dan squat $(\mathrm{G})$, ruang bebas bersih untuk alur sebesar 10\%-15\% dari draft kapal (R) dan ketelitian pengukuran $(\mathrm{P})$. Hasil penentuan batas kedalaman dapat dilihat pada Tabel 3.

Gambar 3 merupakan kedalaman area Pantai Boom dengan elevasi terhadap LLWL. Area tersebut dibagi menjadi 4 bagian kedalaman yaitu:

1) Batas kedalaman Yacht $12: \geq 4,057 \mathrm{~m}$

2) Batas kedalaman Yacht $8: \geq 3,074$ meter

3) Batas kedalaman Yacht $6: \geq 2,693$ meter

4) Batas kedalaman $\leq 2,693$ meter

Dari gambar 3 tentang kedalaman area Pantai Boom, terdapat 
beberapa area yang tidak dapat dilalui oleh beberapa jenis kapal tertentu yaitu:

1) Pada area yang diberi nomor 1 dengan lokasi di koordinat 213744; 9091959 tidak bisa dilewati Kapal Yacht 12 yang memiliki lebar 3,6 meter dan draft 2,8 meter, Kapal Yacht 8 yang memiliki lebar 2,51 meter dan draft 1,98 meter, dan Kapal Yacht 6 yang memiliki lebar 1,83 meter dan draft 1,68 meter. Sebaiknya area tersebut dijauhi \pm 30 meter dari koordinat tersebut.

2) Pada area yang diberi nomor 2 dengan lokasi di koordinat 211974; 9092119 tidak bisa dilewati Kapal Yacht 12. Sebaiknya area tersebut dijauhi \pm 10 meter dari koordinat tersebut.

3) Pada area yang diberi nomor 3 dengan lokasi di koordinat 212266; 9092208 tidak bisa dilewati kapal Yacht 12. Sebaiknya area tersebut dijauhi \pm 60 meter dari koordinat tersebut.

4) Pada area yang diberi nomor 4 dengan lokasi di koordinat 212310; 9092632 tidak bisa dilewati Kapal Yacht 12. Sebaiknya area tersebut dijauhi \pm 200 meter dari koordinat tersebut.

5) Pada area yang diberi nomor 5 dengan lokasi di koordinat 212454; 9093607 tidak bisa dilewati Kapal Yacht 12. Sebaiknya area tersebut dijauhi \pm 80 meter dari koordinat tersebut.

6) Sedangkan pada area lainnya, di sebelah selatan Pantai Boom, daerah $\pm 150-400$ meter ke arah timur dari garis pantai tidak bisa dilewati oleh Kapal Yacht 12, 8, dan 6.

7) Pada area sebelah utara Pantai Boom, daerah $\pm 250-400$ meter ke arah timur dari garis pantai tidak bisa dilewati oleh Kapal Yacht 12, 8, dan 6.

\section{Analisis Desain Alur Pelayaran}

Dermaga yang sesuai dengan daerah studi adalah dermaga dengan tipe jetty. Jetty adalah dermaga yang dibangun menjorok cukup jauh ke arah laut, dengan maksud agar ujung dermaga berada pada kedalaman yang cukup untuk kapal merapat [6]. Dermaga ini sebaiknya dibangun 60 meter menjorok ke arah laut. Panjang dermaga ditentukan dengan rumus [6]:

$$
L_{p}=n L_{o a}+(n+1) \times 10 \% \times L_{o a}
$$

\section{dengan:}

$L_{p} \quad=$ panjang dermaga

$L_{o a}=$ panjang kapal yang ditambat

$n \quad=$ jumlah kapal yang ditambat

Jadi untuk satu kapal Yacht 12 dibutuhkan panjang dermaga $\mathrm{Lp}=1(21,40)+(1+1) \times 10 \%(21,40)=25$ meter.

Tabel 4

Spesifikasi Desain Alur Pelayaran Kapal

\begin{tabular}{cccc}
\hline \hline & Yacht Class & Yacht Class & Yacht Class \\
& 12 & 8 & 6 \\
\hline Lebar alur satu arah & 16,212 & 9,944 & 8,573 \\
Lebar alur dua arah & 25,219 & 15,469 & 13,335 \\
Kedalaman & 3,948 & 3,061 & 2,521 \\
\hline \hline
\end{tabular}

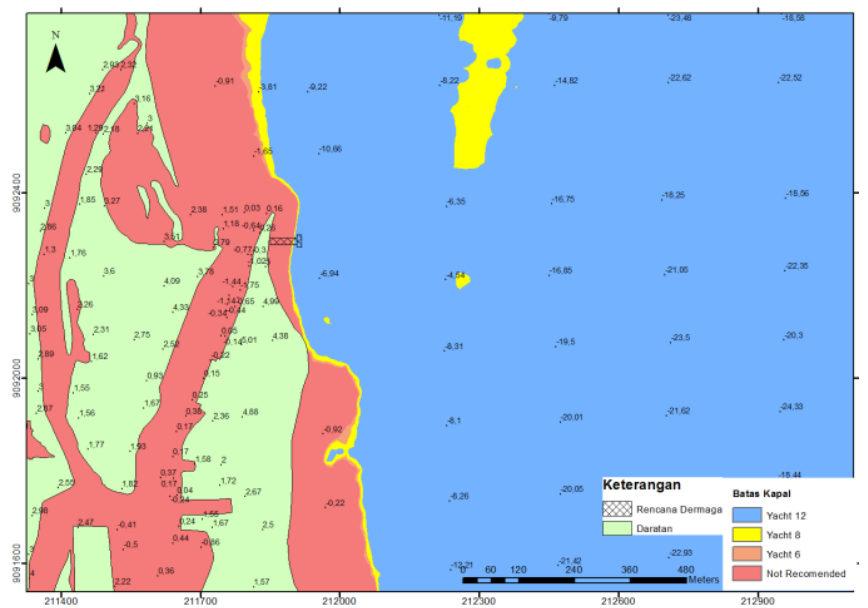

Gambar. 4. Keadaan Alur Pelayaran LLWL

Desain alur pelayaran pada daerah Pantai Boom ini disesuaikan dengan spesifikasi kapal-kapal yang direncanakan untuk berlayar di daerah tersebut yaitu jenis kapal yacht.

Spesifikasi alur pelayaran meliputi ketentuan lebar alur dan kedalaman alur. Ketentuan lebar alur diperoleh dengan menggunakan rumus:

$$
\begin{aligned}
& L=d+2 f \\
& L=2 d+2 f+s
\end{aligned}
$$

\section{Keterangan:}

$\mathrm{d}=$ Lebar untuk pergerakan horisontal kapal yang disebabkan alur pelayaran yang tidak searah dengan arus air, sebesar 1,2-1,5 lebar kapal

$\mathrm{s}=$ Faktor pengaman antara dua kapal, sebesar 1 kali lebar kapal

$\mathrm{f}=$ Faktor pengaman antara sisi alur, sebesar 1,5 lebar kapal

Rumus 7 [7] merupakan rumus untuk menentukan alur pelayaran satu arah, sedangkan rumus 8 [8] merupakan rumus untuk menentukan alur pelayaran dua arah. Untuk ketentuan kedalaman alur digunakan rumus 5. Spesifikasi alur dapat dilihat dalam Tabel 4.

Setelah diketahui spesifikasi alur pelayaran, langkah selanjutnya adalah merencanakan alur pelayaran yang aman bagi kapal-kapal tersebut sesuai dengan lokasi pelayarannya. Untuk desain alur pelayaran, digunakan kedudukan muka air rendah terendah sebagai acuan untuk keperluan navigasi, oleh karena itu acuan untuk penentuan alur pelayaran digunakan muka air rendah terendah (LLWL) yang didapatkan dari hasil pengamatan pasang surut Pantai Boom, Banyuwangi selama 15 hari. Skema alur pelayaran dibandingkan dengan draft jenisjenis kapal dapat dilihat pada Gambar 4. 
Tabel 4.

Daerah yang tidak bisa dilewati saat LLWL

\begin{tabular}{|c|c|c|c|}
\hline \multicolumn{2}{|c|}{ Koordinat } & \multirow{2}{*}{$\begin{array}{r}\text { Jenis kapal yang } \\
\text { tidak bisa lewat }\end{array}$} & \multirow{2}{*}{ Dijauhi sebesar } \\
\hline Northing & Easting & & \\
\hline 213744 & 9091959 & Yacht 12,8 , dan 6 & \pm 30 meter \\
\hline 211974 & 9092119 & Yacht 12 & \pm 10 meter \\
\hline 212266 & 9092208 & Yacht 12 & \pm 60 meter \\
\hline 212310 & 9092632 & Yacht 12 & \pm 200 meter \\
\hline 212454 & 9093607 & Yacht 12 & \pm 80 meter \\
\hline
\end{tabular}

Dapat dilihat pada Gambar 4, bahwa dalam keadaan air rendah terendah (LLWL), ketiga jenis kapal yang sudah disebutkan sebelumnya dapat merapat ke rencana Dermaga Pelabuhan Marina Pantai Boom, Banyuwangi.

Namun pada saat LLWL, ketiga jenis kapal tidak dapat melewati perairan sungai Pantai Boom. Pada saat LLWL ada beberapa daerah yang kedalamannya tidak sesuai sehingga tidak bisa dilewati salah satu dari ketiga jenis kapal yang sudah ditentukan. Daerah dengan kedalaman yang tidak sesuai dapat dilihat pada Tabel 5. Sebagai perbandingan, akan diberikan juga kondisi air pada keadaan lainnya yaitu pada keadaan tinggi air rerata (MSL) dan pada keadaan muka air tinggi tertinggi (HHWL).

Pada keadaan MSL seperti Gambar 5, ketiga jenis kapal yang sudah disebutkan dapat merapat ke rencana Dermaga Pelabuhan Marina Pantai Boom, Banyuwangi dan ketiga jenis kapal tersebut masih tidak dapat melewati perairan sungai Pantai Boom, Banyuwangi. Namun daerah yang tidak bisa dilewati pada saat LLWL seperti pada Tabel 5, pada saat MSL daerah tersebut sudah mempunyai kedalaman yang sesuai dengan ketiga jenis kapal atau daerah tersebut dapat dilewati oleh ketiga jenis kapal tersebut.

Sedangkan pada keadaan (HHWL) seperti Gambar 6, Kapal Yacht Class 8 dapat melewati sebagian perairan sungai Pantai Boom. Sedangkan jenis Kapal Yacht 6 dapat melewati perairan sungai Pantai Boom lebih jauh. Keadaan muka air tinggi tertinggi (HHWL) tentunya tidak dianjurkan untuk dijadikan sebagai acuan navigasi pelayaran karena faktor keamanan yang rendah, oleh karena itu keadaan alur pelayaran ini hanya dapat dilewati pada waktu tertentu saja yaitu pada saat permukaan air sedang berada muka air tinggi tertinggi.

Waktu yang tidak tepat dalam melakukan pelayaran dapat dilihat pada Tabel 6. Dapat dilihat dalam Tabel 6 bahwa waktu yang tidak tepat yaitu antara pukul 04:00 - 06:00 WIB pada saat bulan November 2015-Februari 2016 dan pukul 16:00-18:00 pada saat bulan Juni-Agustus 2016. Waktu tersebut tidak tepat karena pada waktu tersebut tinggi air lebih rendah dari LLWL yang sudah ditentukan.

Waktu yang tepat untuk melakukan pelayaran pada saat HHWL yaitu antara pukul 20:00-23:00 WIB pada saat bulan Desember 2015-Maret 2016 dan pukul 8:00-11:00 pada saat bulan Juni-September 2016. Waktu tersebut merupakan waktu yang tepat untuk melakukan pelayaran saat keadaan HHWL karena pada waktu tersebut tinggi air lebih tinggi dari HHWL yang sudah ditentukan.

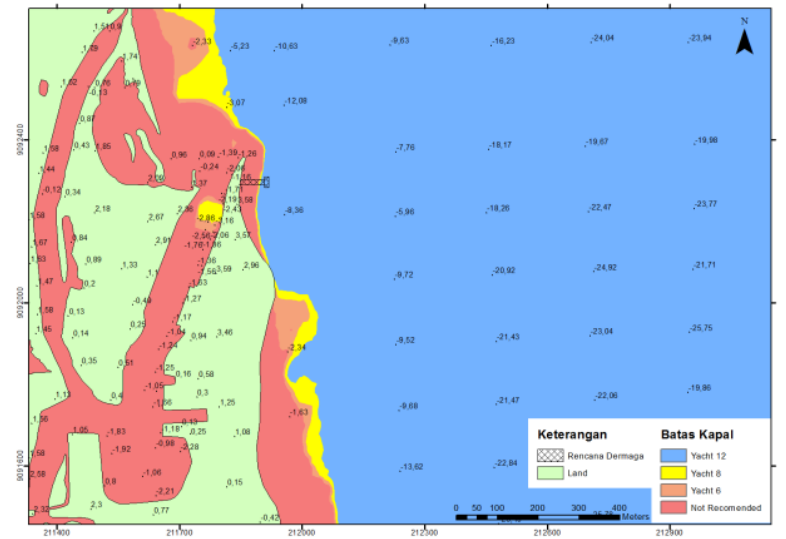

Gambar. 5. Keadaan Alur Pelayaran MSL

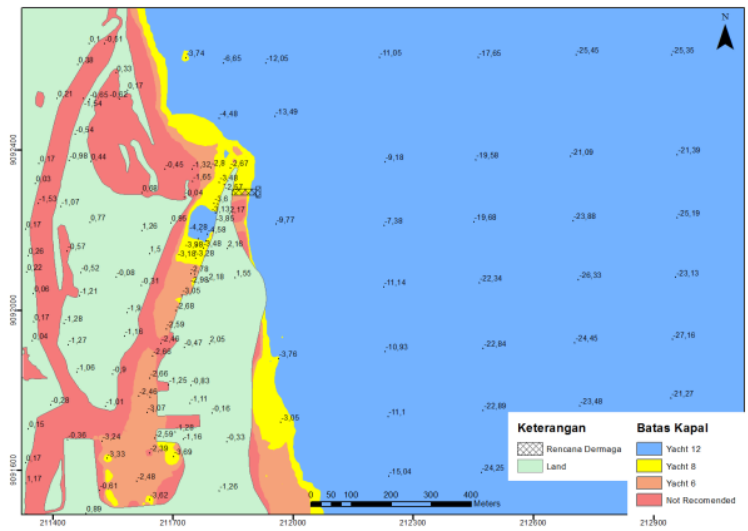

Gambar. 5. Keadaan Alur Pelayaran HHWL

Tabel 6.

Waktu yang Tidak Tepat Dalam Melakukan Pelayaran

\begin{tabular}{|c|c|c|c|c|c|}
\hline Tanggal & $\begin{array}{l}\text { Pukul } \\
\text { (WIB) }\end{array}$ & $\begin{array}{l}\text { Tinggi } \\
\text { Air }(\mathrm{m})\end{array}$ & Tanggal & $\begin{array}{l}\text { Pukul } \\
\text { (WIB) }\end{array}$ & $\begin{array}{l}\text { Tinggi } \\
\text { Air (m) }\end{array}$ \\
\hline $27 / 11 / 2015$ & $4: 00$ & -0.114 & $23 / 02 / 2016$ & $4: 00$ & -0.028 \\
\hline $28 / 11 / 2015$ & $5: 00$ & -0.191 & 05/06/2016 & $16: 00$ & -0.147 \\
\hline $29 / 11 / 2015$ & $5: 00$ & -0.133 & $06 / 06 / 2016$ & $16: 00$ & -0.169 \\
\hline $29 / 11 / 2015$ & $6: 00$ & -0.134 & $06 / 06 / 2016$ & $17: 00$ & -0.239 \\
\hline $13 / 12 / 2015$ & $5: 00$ & -0.126 & $07 / 06 / 2016$ & 17:00 & -0.269 \\
\hline $14 / 12 / 2015$ & $5: 00$ & -0.139 & $07 / 06 / 2016$ & 18:00 & -0.183 \\
\hline $15 / 12 / 2015$ & $6: 00$ & -0.132 & 08/06/2016 & $17: 00$ & -0.121 \\
\hline $26 / 12 / 2015$ & 4:00 & -0.249 & 08/06/2016 & 18:00 & -0.221 \\
\hline $26 / 12 / 2015$ & $5: 00$ & -0.174 & $21 / 06 / 2016$ & $17: 00$ & -0.127 \\
\hline $27 / 12 / 2015$ & 4:00 & -0.224 & $22 / 06 / 2016$ & $17: 00$ & -0.170 \\
\hline $27 / 12 / 2015$ & $5: 00$ & -0.331 & $23 / 06 / 2016$ & $17: 00$ & -0.110 \\
\hline $28 / 12 / 2015$ & 5:00 & -0.316 & $23 / 06 / 2016$ & 18:00 & -0.141 \\
\hline $28 / 12 / 2015$ & 6:00 & -0.243 & $24 / 06 / 2016$ & 18:00 & -0.105 \\
\hline $29 / 12 / 2015$ & $5: 00$ & -0.147 & 04/07/2016 & $16: 00$ & -0.233 \\
\hline $29 / 12 / 2015$ & $6: 00$ & -0.240 & 05/07/2016 & $16: 00$ & -0.296 \\
\hline $10 / 01 / 2016$ & 4:00 & -0.107 & 05/07/2016 & $17: 00$ & -0.306 \\
\hline $11 / 01 / 2016$ & $5: 00$ & -0.148 & $06 / 07 / 2016$ & $16: 00$ & -0.180 \\
\hline $11 / 01 / 2016$ & $5: 00$ & -0.193 & $06 / 07 / 2016$ & 17:00 & -0.374 \\
\hline $12 / 01 / 2016$ & 6:00 & -0.258 & 06/07/2016 & 18:00 & -0.203 \\
\hline $12 / 01 / 2016$ & $5: 00$ & -0.107 & 07/07/2016 & 17:00 & -0.270 \\
\hline $13 / 01 / 2016$ & $5: 00$ & -0.198 & 07/07/2016 & 18:00 & -0.278 \\
\hline $13 / 01 / 2016$ & 6:00 & -0.198 & 08/07/2016 & 18:00 & -0.191 \\
\hline $14 / 01 / 2016$ & $6: 00$ & -0.157 & $20 / 07 / 2016$ & $16: 00$ & -0.115 \\
\hline $24 / 01 / 2016$ & 4:00 & -0.217 & $21 / 07 / 2016$ & $17: 00$ & -0.193 \\
\hline $25 / 01 / 2016$ & 4:00 & -0.233 & $22 / 07 / 2016$ & $17: 00$ & -0.185 \\
\hline $25 / 01 / 2016$ & $5: 00$ & -0.235 & $22 / 07 / 2016$ & 18:00 & -0.104 \\
\hline $26 / 01 / 2016$ & $5: 00$ & -0.260 & $23 / 07 / 2016$ & 18:00 & -0.121 \\
\hline $27 / 01 / 2016$ & $5: 00$ & -0.143 & 02/08/2016 & $16: 00$ & -0.130 \\
\hline $27 / 01 / 2016$ & $6: 00$ & -0.119 & 03/08/2016 & $16: 00$ & -0.227 \\
\hline $09 / 02 / 2016$ & 4:00 & -0.097 & 03/08/2016 & $17: 00$ & -0.126 \\
\hline $10 / 02 / 2016$ & 4:00 & -0.070 & $04 / 08 / 2016$ & $16: 00$ & -0.157 \\
\hline $10 / 02 / 2016$ & 5:00 & -0.127 & 04/08/2016 & $17: 00$ & -0.227 \\
\hline $11 / 02 / 2016$ & 5:00 & -0.119 & 05/08/2016 & $17: 00$ & -0.171 \\
\hline $12 / 02 / 2016$ & 6:00 & -0.019 & & & \\
\hline
\end{tabular}




\section{KESIMPULAN}

Berdasarkan hasil penelitian tugas akhir ini, didapat kesimpulan antara lain:

1) Rencana Dermaga sebaiknya dibangun 60 meter menjorok ke arah laut. Panjang Dermaga 25 meter untuk satu kapal Yacht 12 yang merapat.

2) Dalam keadaan air rendah terendah (LLWL), ketiga jenis kapal yang ditentukan dapat merapat ke rencana Dermaga Pelabuhan Marina Pantai Boom, Banyuwangi. Daerah yang tidak bisa dilewati pada saat LLWL, pada saat MSL daerah tersebut sudah dapat dilewati oleh ketiga jenis kapal tersebut. Sedangkan pada keadaan muka air tinggi tertinggi (HHWL), Kapal Yacht Class 8 dan 6 dapat melewati sebagian perairan sungai Pantai Boom.

3) Waktu yang tidak tepat untuk melakukan pelayaran pada saat LLWL dari alur pelayaran yang telah dibuat yaitu antara pukul 04:00 - 06:00 WIB pada saat bulan November 2015-Februari 2016 dan pukul 16:00-18:00 pada saat bulan Juni-Agustus 2016. Sedangkan Waktu yang tepat untuk melakukan pelayaran pada saat HHWL yaitu antara pukul 20:00-23:00 WIB pada saat bulan Desember 2015- Maret 2016 dan pukul 8:00-11:00 pada saat bulan Juni-September 2016.

Saran dari penelitian ini adalah perlu ditambahkan data fitur dasar laut, arus, dan gelombang sebagai parameter tambahan dalam menentukan alur pelayaran.

\section{UCAPAN TERIMA KASIH}

Penulis MDD mengucapkan terima kasih kepada Bapak Khomsin, ST. MT, Musthofa Abdurrahman, ST dan A. Nor Fatahni, ST atas kesediaannya untuk membantu dan membimbing dalam penelitian ini.

\section{DAFTAR PUSTAKA}

[1] S. A., W. S. and S. H., "Pemetaan Batimetri untuk Alur Pelayaran Pe;abuhan Pvnyeberangan Mororejo Kabupaten Kendal," Jurnal Oseanografi, pp. 284-293, 2014.

[2] O. O. and Suyarso, "Pasang Surut," LIPI, Pusat Penelitian dan Pengembangan Oseanologi, Jakarta, 1989.

[3] D. E. and Poerbandono, Survei Hidrogafi, Bandung: PT. Refika Aditama, 2005.

[4] S. R. Z., "Pekerjaan Survei Hidrogafi dan Perencanaan Alur Pelayaran dalam Usaha Transportasi Hasil Pertambangan Batubara," Teknik Geodesi dan Geomatika FITB-ITB, Bandung, 2012.

[5] G. H. R. and R. M. C., Sailing Yacht Design, Cambridge: Cornell Maritime Press Inc., 1965.

[6] T. B., Perencanaan Pelabuhan Yogyakarta, Yogyakarta: Beta Offset, 2009.

[7] K. S., "Perencanaan Pelabuhan," ITB, Bandung, 2002.

[8] N. S., "Survei Hidrografi dan Pelaksanaan Pengerukan Alur Pelayaran Pelabuhan," Program Studi Teknik Geodesi dan Geometika FTIB-ITB, Bandung, 2008. 